\title{
Strategy for Multidimensional Peatland Ecosystem Analysis in the Context of the Atmospheric Properties
}

\author{
Kamila M. Harenda ${ }^{1, *}$, Patryk Poczta ${ }^{1,2}$, Dominika Szczepanik ${ }^{3}$, Dongxiang Wang ${ }^{3}$, Iwona S. Stachlewska ${ }^{3}$, \\ and Bogdan H. Chojnicki ${ }^{1}$ \\ ${ }^{1}$ Department of Meteorology, Faculty of Environmental Engineering and Spatial Management, \\ Poznań University of Life Sciences, 60-649 Poznań, Poland \\ ${ }^{2}$ Department of Grassland and Natural Landscape Sciences, Faculty of Agronomy and Bioengineering, \\ Poznań University of Life Sciences, 60-632 Poznań, Poland \\ ${ }^{3}$ Institute of Geophysics, Faculty of Physics, University of Warsaw, 02-093 Warsaw, Poland
}

\begin{abstract}
There is the need of integration of atmospheric and ecosystem research in order to assess the habitats reaction in the future since the recent climate changes. Peatlands due to their vulnerability are important ecosystems since their strong interaction with the climate system. In stable climatic conditions, they are atmospheric carbon sinks. The study of the atmosphere properties in the context of peatlands productivity requires the application of the multidimensional strategy of field measurements. These kind of measurements are conducted using the following sensors: sun photometer, cloud radar, Raman lidar and eddy covariance (EC) system. They are located and operated at the Rzecin peatland in the framework of the POLIMOS project. So far, aerosols presence in the air was found as a factor that increases the peatland production. This presents the novel strategy of extensive atmospheric studies in order to identify the selected particles type impact on peatlands carbon uptake capabilities.
\end{abstract}

\section{Introduction}

Peatlands are generally the net carbon sink and one of the largest organic carbon stock in the biosphere $[1,2]$, even if they cover only $3 \%$ of the terrestrial area on the Earth [3]. They are very complex ecosystems and their existence and biological richness strictly depend on climate and water supply.

The factors that determine the peat accumulation are divided into two groups, biotic and abiotic one. The biotic controls such as the vegetation types, its physiological status and stage of development [4-8] while the abiotic controls are precipitation [9], water table level [9-11], temperature [12-14], radiation and its properties [15-17].

The clouds and aerosols are two important variables responsible for the solar radiation modification e.g. attenuation and scattering and consequently the capacity to accumulate carbon dioxide in the plant structure [18]. While the attenuation usually causes the reduction of plant $\mathrm{CO}_{2}$ uptake, the solar radiation scattering can substantially increase the net ecosystem production [15, $19,20]$. There are many studies in the literature where the positive impact of scattered radiation on $\mathrm{CO}_{2}$ uptake is presented [21, 22]. On the other hand, the impact of the optical properties of the atmosphere parameters on ecosystems production is poorly described. A lot of studies base on diffuse index (DI) (proper name scattering index SI) as determinant of sunny or clear sky $(\mathrm{DI}<0.3)$ and cloudy (DI>0.7) conditions. This factor is defined as the ratio between the diffuse and global radiation that reaches the Earth's surface $[16,23]$. This simple index doesn't describe atmospheric conditions in details. Thus, the presented multidimensional strategy of studies enables to assess the cloud and/or aerosol impact on radiation scattering process in the atmosphere. The peatlands $\mathrm{CO}_{2}$ uptake is the result of the processes that are driven by different factors [24] but these ecosystems are very vulnerable to climate changes. Thus, predicted temperature increase and precipitation seasonal patterns modifications can transform these ecosystems into the net carbon sources [25]. However, the impact of the shifts of solar radiation scattering phenomenon on peatlands production still requires more investigation. The recent advance of the atmospheric surveys led to development of novel techniques which provide the knowledge about the amount and properties of the particles suspended in the atmosphere [26, 27].

There are two groups of the aerosols that are present in the atmosphere: the anthropogenic and the natural one. The first group is mainly consisted of black carbon, sulfates, nitrate, and ammonium while the group of

Corresponding author: kamila.harenda@up.poznan.pl 
natural aerosols contains such substances as mineral dust, sea salt, and primary biological aerosol particles [28]. It is difficult to estimate aerosols' impact on the climate since their concentration and properties varies in time and space. The dominant the aerosol type in the air mass can be a place of occurrence dependent. The mineral dust (approx. 35\%) dominates at urban sites of South Asia and China, while organic carbon $(20 \%$ or more) is observed at urban areas of North and South America. The sea salt is dominating (50-70\%) aerosol type at remote oceanic locations. Sulphate is observed usually at the level of 10 to $30 \%$ of the total aerosol mass while the nitrate and the ammonium are in the average $6 \%$ and $4 \%$, respectively. The elementary carbon content is less than $5 \%$, but it can be higher in some regions e.g. urban part of Europe approx. 12\% [28]. The aerosols transform in the atmosphere and this is result of their mutual interaction and/or reaction with other components of the air. The products of these conversions affect the optical properties of the atmosphere such as reflectivity, scattering intensity and absorptivity [29]. The aerosol volume increases within the process of the low-volatility vapours condensation on aerosol particles surfaces. The particles growth can be also realized by the small aerosol particles coagulation.

The aerosols determine the clouds formation processes and this interaction has crucial impact on clouds properties as well e.g. chemical composition, morphology, mixing state and particle size impact [30]. The average Earth's cloud cover is around $60 \%$ so its impacts on weather and atmosphere properties modification is not negligible. Clouds can cause both cooling or warming of the climate. First, they can reflect part of solar radiation and second, they can absorb and keep heat radiation radiated from the ground. Furthermore, the cloud albedo depends on their types. Reflectivity coefficient of Cirrus, Stratus, Cumulus and Cumulonimbus is approx. 20-40, 40-65, 75 and $90 \%$ respectively.

These feedbacks found between aerosols and clouds [31] makes the modelling of the aerosols on a global scale extremely difficult [28, 32]. Due to this reason, particular attention should be paid for the research of the interaction between the aerosols and clouds. They mutual effects strongly influence the surface solar radiation flux density and the Earth's heat balance [33, 34].

The monitoring of particles in the atmosphere is usually carried out due to the fact that the presence of the aerosols and clouds in the air modify substantially the climate system parameters. The atmospheric observations can include both in-situ and remote sensing techniques. Ground based instruments usually act within networks (e.g. Poland AOD, AERONET, EARLINET) where standardized data processing techniques are applied. These networks coverage ranges usually from local, through regional to global scale $[35,36]$.

The ecosystem observations provide the estimation of heat and mass (e.g. water and carbon dioxide) exchange between their active surface and the atmosphere [37].
The combination of the air particles/clouds and ecosystem production measurements provides the basis for development of complex models which allow to separate the air optical properties impact on the ecosystem $\mathrm{CO}_{2}$ uptake [24]. This studies are crucial due to the fact that peatlands play an important role in the global carbon budget and they reaction on atmospheric optical properties change is linked directly with $\mathrm{CO}_{2}$ concentration in the atmosphere.

The main goal of this study was the presentation of the scientific approach that will provide the basis for the comprehensive study the air optical properties impact on the Rzecin peatland $\mathrm{CO}_{2}$ uptake.

\section{Site description}

The measurements were carried out at the PolWET site that is placed in Rzecin village $\left(52^{\circ} 45^{\prime} \mathrm{N}, 16^{\circ} 18^{\prime} \mathrm{E}\right.$, ca. $54 \mathrm{~m}$ a.s.1.) approximately $70 \mathrm{~km} \mathrm{NW}$ of Poznań in Poland [38]. The Rzecin peatland is located in the centre of the village and it is classified as a transitional peatland. The continuous measurements of clouds reflectivity, aerosol optical thickness, and $\mathrm{CO}_{2} / \mathrm{H}_{2} \mathrm{O} /$ heat fluxes are carried out at the station since March 2018, May 2016 and January 2004, respectively. These devices are all co-located measurements and these activities are realized in the framework of the Technical assistance for Polish Radar and Lidar Mobile Observation System (POLIMOS) project founded by European Space Agency (ESA).

\section{Atmospheric measurements}

Since the necessity of atmospheric optical properties surveys, our activities were focused on the permanent or semi-permanent observations of clouds and aerosols suspended in the atmosphere. The comprehensive description of the optical properties of the air is achieved by simultaneous observations of cloud, aerosol and aerosol optical thickness (AOT) with application of the following devices: cloud radar, lidar and sun photometer, respectively. These instruments and their operation have been described below.

\subsection{Clouds, precipitations and fog}

Clouds consist of droplets of water and/or ice crystals. These particles can be detected using passive or active methods. Passive observations (like sky camera) cannot answer specific questions about e.g. type of particles but active observations using instruments like radars make possible to study clouds more detailed.

\subsubsection{Radar}

This active microwave remote sensor was primarily used for the detection of ships and aircraft and for determining their ranges, and then was applied for other purposes e.g. rain detection. The principle of the radar operation is based on measurements of time delay between 
transmitted and received wave [39]. Recent progress of radar technology led to development of novel radar technique that bases on the frequency modulated signal.

This invention allowed for the continuous cloud remote sensing with e.g. 95-GHz Doppler cloud radar called the Bistatic Radar System for Atmospheric Studies (BASTA). This device was developed by a research team from the Laboratoire Atmosphères, Milieux, Observations Spatiales (LATMOS), Université de Versailles Saint-Quentin-en-Yvelines. The radar uses a frequency-modulated continuous wave (FMCW) technique that significantly reduces the cost of operation compared to traditional pulsed radars [40]. Emitted energy is transmitted continuously without interruption, as in the case of pulsed radar and modulation of the signal frequency is used instead of the pulse. Briefly speaking, the radar measures the reflected energy of the hydrometeors. These structures are defined as liquid or solid water particles that are suspended in the atmosphere (e.g. clouds, fog), blown by the wind from the Earth's surface (e.g. sea aerosol), fall through the atmosphere (precipitation) or deposited on other objects (e.g. dew) [41].

Beside clouds, BASTA is capable to detect and parameterize precipitations and fog events as well. On the basis of BASTA's products (reflectivity $(Z)$ and Doppler velocity (fig. 1.)) it is possible to assess the droplet and ice crystal size. In our latitude, tropospheric profile up to $12 \mathrm{~km}$ is obtain.

Reflectivity $\mathrm{Z}$ represents the mean reflectance of particles enclosed in a volume of space and is substantially expressed in units $\mathrm{m}^{6} / \mathrm{m}^{3}$ or $\mathrm{mm}^{6} / \mathrm{m}^{3}$. Regarding the drop-size distribution $\mathrm{N}(\mathrm{D})$, it can be computed as a continuous function of drop size [42]:

$$
Z=\int_{D \min }^{D \max } N(D) D^{6} d D
$$

Reflected energy depends on the water and/or ice content in clouds and the size of the particles. In the analysis of radar signals, the logarithmic scale is commonly used. To specify the radar reflectivity in decibels of reflection (dBZ), the following conversion is used [43]:

$$
Z(d B Z)=10 \log \left(Z\left[\frac{m^{6}}{m^{3}}\right]\right)
$$

BASTA operates in three vertical resolution modes that depend either on cloud conditions or on the object being tested. There are $12.5 \mathrm{~m}$ (fog and low clouds study), $25 \mathrm{~m}$ (liquid and ice midtropospheric clouds study), and $100 \mathrm{~m}$ (optically thin high-level ice clouds study) with the maximum range of $6 \mathrm{~km}, 12 \mathrm{~km}$, and 18 $\mathrm{km}$ (24 km - extended range), respectively [40].

Combining radar data with other measurements allows to describe atmospheric situation in details.
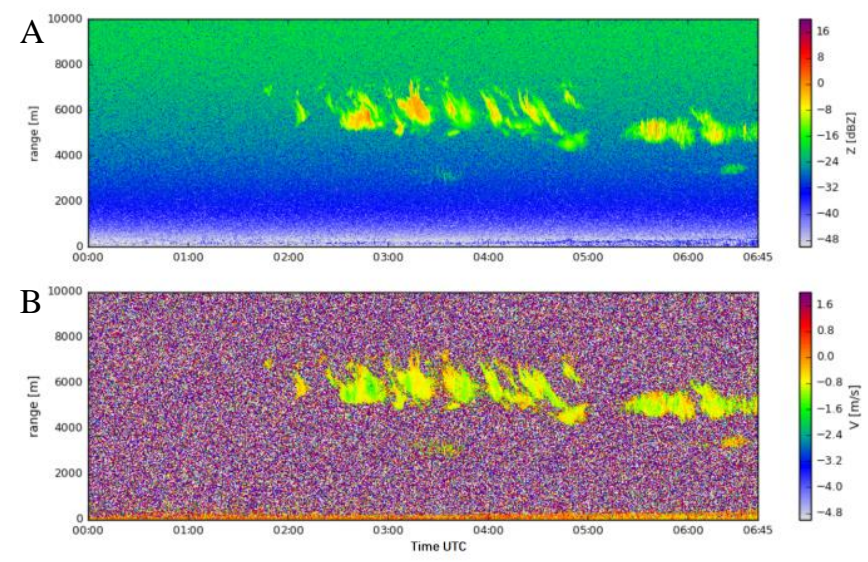

Fig. 1. Radar reflectivity $Z$ (A) and Doppler velocity (B). The data was obtained on 22.05.2018 00:00-06:45 UTC at the Rzecin peatland.

\subsection{Aerosols}

Atmospheric aerosols still require investigation since these suspended particles modify substantially the strength of the radiative forcing observed in the troposphere.

The detection of atmospheric aerosols can be carried out with both passive (e.g. photometers) and active (e.g. lidars) devices. The combination of lidar and photometric measurements enable us to study the microphysical aerosol properties in more detailed [44].

\subsubsection{Raman LiDAR}

The atmosphere of Earth is highly variable both in time and space. By means of remote sensing techniques and it is possible to observe its changes in real time by various devices. One is Light Detection And Ranging (LiDAR), which emits a light pulses at specific wavelengths, and then collects the radiation reflected by molecules and particles suspended in the air on a telescope, and separates signals in wavelength detection unit [45]. By means of lidar instrument, the quantitative and qualitative assessment of aerosols, as well as a rough estimation of particles concentration are possible. Remote sensing observations of aerosol particles in the atmosphere over the Rzecin peatland are being carried out by ESA Mobile Raman Lidar (EMORAL). EMORAL was built by Raymetrics company through close cooperation with the University of Warsaw and Ludwig - Maximilians - University of Munich. A light source is a Nd-YAG laser, (SpitLight 400, InnoLas, Germany), emitting pulses at wavelengths: 355/532/1064 $\mathrm{nm}$ at $10 \mathrm{~Hz}$ frequency. The signals are collected through a $30 \mathrm{~cm}$ large telescope. Collected radiation is separated and filtered by a wavelengths Separation Unit (WSU) composed of polarizing beam splitter cubes (PBCs), interference filters, lenses and photomultiplier tubes (PMT) [46]. The signal is detected on 8 channels: 3 elastic (355/532/1064 nm), 3 inelastic Raman (387 and $607 \mathrm{~nm}$ for $\mathrm{N}_{2}$, and $408 \mathrm{~nm}$ for $\mathrm{H}_{2} \mathrm{O}$ ) and 2 elastic crosspolarized (355 and $532 \mathrm{~nm})$. All signals are simultaneously recorded using the analog and photon- 
counting methods (TR 40-160, 16 bits, Licel, Germany), except $1064 \mathrm{~nm}$ (only analog method) [47]. Through different wavelengths in various configurations, which EMORAL is able to measure, it is possible to observe presence of different particles in the atmosphere e.g. small ones such us sulfates and soot, fraction of smallsize mineral-dust particles, as well as to some extend also larger particles and hydrometeors such as clouds, ice crystals and hail [48]. The simplest form of the detected Lidar signal is as follows [45]:

$$
P(r)=K \cdot O(r) \cdot \beta(r) \cdot T(r)
$$

Where:

$K$ is a Lidar system constant, $\mathrm{O}(r)$ is a range dependent measurement geometry, both variables result from the design and components of the device. backscattering coefficient at range $(r)$ describes $\beta(r)$, and transmission $T(r)$ describes the losses of the emitted signal. The latter both variables depend on atmospheric conditions during the measurement. The LiDAR equation in a more detailed form reads $[45,48,49]$ :

$$
P(r)=P_{0} \cdot \frac{c \tau}{2} \cdot \eta \cdot A \cdot \frac{O(r)}{r^{2}} \cdot \beta(r) \cdot \exp \left[-2 \int_{0}^{r} \alpha(r) \cdot d r\right]+P_{b g r}
$$

where:

$$
\begin{aligned}
& \beta(r)=\beta_{\text {mol }}(r)+\beta_{\text {aer }}(r) \\
& \alpha(r)=\alpha_{\text {mol }}(r)+\alpha_{a e r}(r)
\end{aligned}
$$

$P_{0}$ is the average power of a single laser pulse, $c$ is the speed of light, $\tau$ is the duration of the laser pulse, $\eta$ describes the optical efficiency of system components (overall system efficiency) and $A$ is a telescope area. The overlap geometric form factor $O(r)$ determines whether the laser beam is fully detected by the telescope. The raw signal includes background $\left(P_{b g r}\right)$ solar radiation during daytime and electronic noise. The background is subtracted before starting the signal analysis. The most important variables are extinction coefficient $\alpha(\mathrm{r})$ and backscattering coefficient $\beta(\mathrm{r})$, by means of which one can determine the type of aerosol particles suspended in the air. Extinction occurs due to scattering and absorption of light by particles and molecules, while backscattering coefficient describes how much light is scattered backwards onto the lidar receiver, and consequently is the basic atmospheric parameter determining the lidar signal strength. Lidar measures total extinction and backscattering coefficients, from which the aerosol extinction and backscattering coefficients (index aer) can be calculated by subtracting the molecular (index $\mathrm{mol}$ ) component (usually obtained from radiosounding). Signals collected during laser measurements are automatically processed into a graphic form of quick-looks (fig. 2), which allows assessing the aerosol/cloud atmospheric situation.

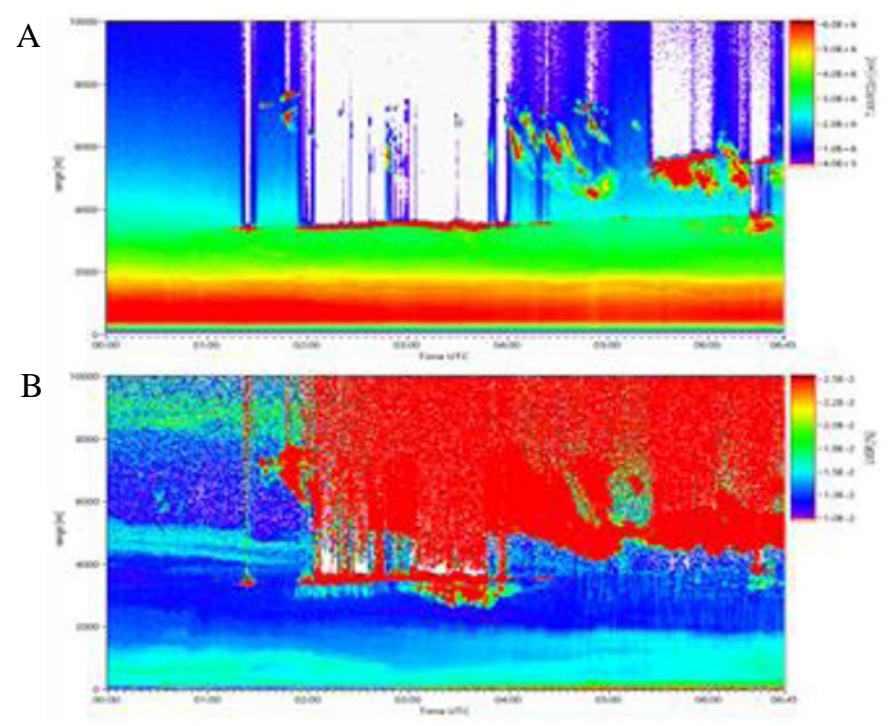

Fig. 2. Backscattering coefficient - background and range corrected signal at the $355 \mathrm{~nm}$ - analog sensor (A) and linear volume depolarization ratio at $355 \mathrm{~nm}$ (B). The data was obtained on 22.05.2018 00:00-06:45 UTC at the Rzecin peatland.

\subsubsection{Sun photometer}

A multiband automatic sun photometer CE318 (CIMEL Electronique, France) is the ground based passive remote sensing instrument installed at the Rzecin peatland at a 4 $\mathrm{m}$ high tower. It is an autonomous equipment that carries out continuous observations on a fully automatic mode [50].

In principle, this device measures the solar radiation attenuation that is caused by the presence of atmospheric aerosols above the sun photometer.

During a single measurement, the robotic sensor head is aiming at the sun disk and the observations are completed when the path between the sensor and sun is free of clouds. The measurements of the AOT are conducted simultaneously within 9 spectral bands 340 , $380,440,500,675,870,940,1020$ and $1640 \mathrm{~nm}[51$, 52]. This sun photometer is integrated within the Aerosol Robotic Network (AERONET) and operates under a standardized measurement protocol. This particular instrument is set up to measure both spectral sun and sky irradiances.

The measured values are automatically transmitted and collected in the framework of the AERONET, where the data is processed and presented at the organization's website [51]. The AERONET provides also the standardized calibration procedure for each device to improve the quality of collected data. The sensor characteristics obtained within the calibration process are used for correction of the previously obtained data.

\section{Ecosystem measurements}

Field measurements of $\mathrm{CO}_{2}$ uptake are fundamental for the estimation the productivity of the entire ecosystem. Thus, the eddy covariance (EC) technique [37] is applied 
to measure the net ecosystem production (NEP) at the Rzecin peatland [38]. The system operates in a continuous mode that basically consists of two devices: the sonic anemometer (R3-50, Gill Ltd., Limington UK) and the $\mathrm{H}_{2} \mathrm{O} / \mathrm{CO}_{2}$ infrared gas analyser (LI-7200, LICOR, Lincoln USA). Fast and accurate measurements of $\mathrm{CO}_{2}$ concentrations and vertical wind speed component fluctuations are used for the calculations of net $\mathrm{CO}_{2}$ flux density using the following formula [53]:

$$
F_{C}=\rho_{a} \cdot \overline{w^{\prime} \cdot s^{\prime}}
$$

where:

$$
F_{C}-\text { net } \mathrm{CO}_{2} \text { flux density }\left[\mathrm{g} \cdot \mathrm{m}^{-2} \cdot \mathrm{s}^{-1}\right]
$$

$\rho_{a}$ - average dry air density $\left[\mathrm{g} \cdot \mathrm{m}^{-3}\right]$,

$\boldsymbol{W}^{\prime}$ - wind speed vertical component fluctuation $\left[\mathrm{m} \cdot \mathrm{s}^{-1}\right]$, $\boldsymbol{s}^{\prime}-\mathrm{CO}_{2}$ mixing ratio (dry air) fluctuation $\left[\mathrm{g} \cdot \mathrm{g}^{-1}\right]$.

Both sensors are installed on a $4.5 \mathrm{~m}$ tall tower that is located in the central part of the peatland.

The discontinuities in NEP time series are caused either by technical (e.g. lack of power) or methodological (e.g. lack of turbulence) reasons. Thus, the gap filling procedures have been developed in order to achieve temporal continuity of the time series [54].

The Rzecin EC system is enriched with solar radiation and air temperature sensors, as radiative and thermal factors are main determinants of the ecosystem production. Both global and scattered Photosynthetic Photon Flux Density (PPFD) measurements are carried out using the sunshine sensor (BF5, DeltaT, UK) [55]. Additionally, air relative humidity and temperature are measured (HMP, Vaisala, Finland). Nocturnal values of net ecosystem production are used for the parametrization of ecosystem respiration (Reco) [56] determined by air temperature values. This relationship, in combination with NEP values, is finally used for the assessment of the gross ecosystem production (GEP).

\section{Instrumental synergies}

General idea on instrumental synergies can be assessed by close view on atmospheric situation above the measurement site, which can be characterized on the basis of radar and lidar quick-looks comparison (figs. 1 and 2). Data interpretation can be supported by the analysis of backward-trajectories [57], modeled aerosol observations [58], and global fire data [59]. The analysis of lidar quick-look (fig. 2B) shows highly polarizing layers at a heights of 4.5-5 and $9 \mathrm{~km}$. In addition, the stratification within the boundary layer (due to polarization presence) at 0:00-4:30 UTC is noticeable. This stratification is not observed in backscattering coefficient (fig. 2A). The height of the boundary layer is relatively constant and fluctuates around $2 \mathrm{~km}$. The aerosol concentration in the layer between 4.5 and 5.5 $\mathrm{km}$ is decreasing with time. It seems to disappear after cirrus appearance after 4 UTC. The saturation of the signal is also observed (cloud layer consisting of rather large particles, which results in signal attenuated in/above cloud).

The combined analysis of radar and lidar graphs allows to state that clouds have been likely formed on the aerosol layer. It is confirmed by backwardtrajectories and modeled aerosol observations (not shown here for brevity), which indicated the occurrence of smoke (fires in Scandinavia) and sulfate (from anthropogenic or biogenic (e.g. marine plankton activity) sources) over the Rzecin peatland around 3 UTC on $22^{\text {nd }}$ of May 2018 at the three height: 2 (top of boundary layer), 5 and $9 \mathrm{~km}$.

Radar quick-looks give an information about the height of the clouds base and top, and its internal structure. Comparison of lidar and radar obtained data, enables to distinguish whether lidar observes very strong aerosol clusters or rather clouds (e.g. between 3:00-4:00 UTC a strongly depolarizing layer at a height of about 3 $\mathrm{km}$ is observed and its located right under the cloud base, while it is not found in radar data).

Radar observations provide also information regarding the structure of the cloud droplet movements (up- and down-drafts). The fall of clouds particles between 4:00 and 5:00 UTC is noticed.

The combination of the lidar data with the sunphotometry is crucial for the study of the aerosol optical properties. The derivation of the extinction coefficient at daytime from the lidar data alone is often limited by the high background radiation. The lidar data can be constrained with the photometer column at values to obtain high quality profiling at daytime.

\section{Ecosystem modelling and outlook}

Although research of peatlands is recognized an important scientific topic due to its sensitivity to climate variability, the impact of air optical properties on peatland ecosystems productivity has been rarely investigated. Recently observed trends of atmospheric optical parameters, e.g. global brightening [60], allows for expecting the linkages between incoming solar radiation and its scattering processes with the intensity of vegetation photosynthesis. Integrated aerosol/cloud and ecosystem studies are crucial for better understanding, parametrization, and consequently the peatlands fate prediction.

In the context of ecosystems, their productivity models consider a plant's canopy as a one solid layer ('big leaf') and this simplified approach results in an overestimation of plant canopy photosynthesis [61]. Two-layer models show better agreement between field measurements and simulated values than a big leaf one and this improvement is achieved by including both shaded leaves and scattered solar radiation [62]. The most complex multilayer models present the best estimation of ecosystem production, whereby they base on the photosynthesis estimation at the each sublayer of the entire plants canopy [63].

The research conducted within the POLIMOS, combines techniques briefly described in the above sections, as applied simultaneously over the Rzecin 
peatland. This provides detailed description of both cloud (cloud radar observation) and aerosol (lidar observation) properties, as well as $\mathrm{CO}_{2}$ uptake (EC and meteorological measurements).

This unique data set serves as the basis for the development the complex model that will comprise both the radiative transfer modelling (RTM) and the ecosystem production modelling (EPM) (fig. 3).

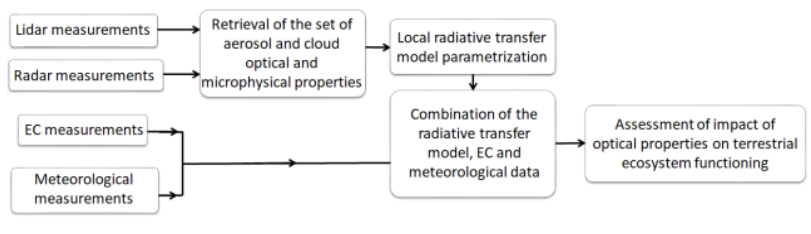

Fig. 3. The block scheme of the research plan.

Generally, EPM estimates direct and scattered radiation fluxes that reach the leafs in the canopy. The upper leafs receive both direct and scattered radiation, while shaded leafs get only the scattered type of solar irradiance. The total canopy $\mathrm{CO}_{2}$ uptake is the sum of the separated parts of whole vegetation layer. The plant canopy structure applied in EPMs differs from simplified (single layer) to complex (multi-layer) one. Finally, the radiative transfer models provides the assessment of direct and scattered radiation fluxes. These values are used as an input data for ecosystem production model.

Both RTM and EPM parametrization will deliver the quantitative ecosystem production where atmospheric optical properties will be taken into account. Such a complex model will be a useful tool for aerosols and/or clouds effect disentangling from the group of factors that determine the peat vegetation photosynthesis.

The Technical assistance for Polish Radar and Lidar Mobile Observation System (POLIMOS) project is coordinated by the Institute of Geophysics, Faculty of Physics, University of Warsaw and funded by the European Space Agency (ESAESTEC) under the Polish Industry Incentive Scheme (PLIIS) with Contract no.4000119961/16/NL/FF/mg.

The core collaborators the POLIMOS projects are University of Warsaw (IG FUW, Poland), Poznan University of Life Sciences (PULS, Poland), Laboratoire Atmosphères, Milieux, Observations Spatiales (LATMOS, France), LudvigMaximilians-Universität (LMU-MIM, Germany), University of Granada (Spain), Raymetrics SA (Greece), Licel GmbH (Germany), Innolas-Lasers GmbH (Germany).

\section{References}

1. E. Lappalainen, General review on world peatland and peat resources, in: E. Lappalainen (ed.) Global Peat Resources (International Peat Society and Geological Survey of Finland, Jyska, Finland, 53-5, 1996)

2. S.E. Page, J.O. Rieley, C.J. Banks, Glob. Chang. Biol. 17, 798-818 (2011)

3. R.S. Clymo, J. Turunen, K. Tolonen, Oikos 81, 368388 (1998)

4. L. Bragazza, Glob. Chang. Biol. 14, 2688-2695 (2008)
5. M. Migliavacca, M. Galvagno, E. Cremonese, M. Rossini, M. Meroni, O. Sonnentag, S. Cogliati, G. Manca, F. Diotri, L. Busetto, A. Cescatti, R. Colombo, F. Fava, U. Morra di Cella, E. Pari, C. Siniscalco, A.D. Richardson, Agric. For. Meteorol. 151, 1325-1337 (2011)

6. O. Sonnentag, M. Detto, R. Vargas, Y. Ryu, B.R.K. Runkle, M. Kelly, D.D. Baldocchi, Agric. For. Meteorol. 151, 916-926 (2011)

7. O. Sonnentag, K. Hufkens, C. Teshera-Sterne, A.M. Young, M. Friedl, B.H. Braswell, T. Milliman, J. O'Keefe, A.D. Richardson, Agric. For. Meteorol. 152, 159-177 (2012)

8. W.L. Bauerle, R. Oren, D.A. Way, S.S. Qian, P.C. Stoy, P.E. Thornton, J.D. Bowden, F.M. Hoffman, R.F. Reynolds, Proc. Natl. Acad. Sci. 109, 8612-17 (2012)

9. B. Robroek, M.G.C. Schouten, J. Limpens, F. Berendse, H. Poorter, Glob. Chang. Biol. 15, 680-691 (2009)

10. A. Yurova, A. Wolf, J. Sagerfors, M. Nilsson, J. Geophys. Res. 112, G02025 (2007)

11. B.N. Sulman, A.R. Desai, N.Z. Saliendra, P.M. Lafleur, L.B. Flanagan, O. Sonnentag, D.S. Mackay, A.G. Barr, G. van der Kamp, Geophys. Res. Lett. 37, L19702 (2010)

12. A. Lindroth, M. Lund, M. Nilsson, M. Aurela, T.R. Christensen, T. Laurila, J. Rinne, T. Riutta, J. Sagerfors, L. Stro M, J.P. Tuovinen, T. Vesala, Tellus B 59, 812-25 (2007)

13. M. Lund, P.M. Lafleur, N.T. Roulet, A. Lindroth, T.R. Christensen, M. Aurela, B.H. Chojnicki, L.B. Flanagan, E.R. Humphreys, T. Laurila, W.C. Oechel, J. Olejnik, J. Rinne, P. Schubert, M.B. Nilsson, Global Change Biol. 16, 2436-2448 (2010)

14. P. McVeigh, M. Sottocornola, N. Foley, P. Leahy, G. Kiely, Agric. For. Meteorol. 194, 8-19 (2014)

15. L.M. Mercado, N. Bellouin, S. Sitch, O. Boucher, C. Huntingford, M. Wild, P.M. Cox, Nature 458, 1014-1017 (2009)

16. O. Urban, D. Janous, M. Acosta, R. Czerny, I. Markova, M. Navratil, M. Pavelka, R. Pokorny, M. Sprtova, R. Zhang, V. Spunda, J. Grace, M.V. Marek, Glob. Chang. Biol. 13, 157-168 (2007)

17. S. Dengel, J. Grace, Oecologia 164, 797-808 (2010)

18. K.D. Kanniah, J. Beringer, P. North, L. Hutley, Progress Phys. Geogr. 36, 209-237 (2012)

19. D.Y. Hollinger, F.M. Kelliher, J.N. Byers, J.E. Hunt, T.M. McSeveny, P.L. Weir, Ecology 75, 134-150 (1994)

20. K. Harenda, M. Piątyszek, B.H. Chojnicki, Acta Agroph. 22, 387-395 (2015)

21. L. Gu, D. Baldocchi, S.B. Verma, T.A. Black, T. Vesala, E.M. Falge, P.R.J. Dowty, Geophys. Res. 107 (2002) 
22. Y. Zhou, X. Wu, W. Ju, J.M. Chen, S. Wang, H. Wang, W. Yuan, T.A. Black, R. Jassal, A. Ibrom, S. Han, J. Yan, H. Margolis, O. Roupsard, Y. Li, F. Zhao, G. Kiely, G. Starr, M. Pavelka, L. Montagnani, G. Wohlfahrt, P. D'Odorico, D. Cook, M.A. Arain, D. Bonal, J. Beringer, P.D. Blanken, B. Loubet, M.Y. Leclerc, G. Matteucci, Z. Nagy, J. Olejnik, K.T. Paw U, A. Varlagin, J. Geophys. Res. Biogeosci. 121, 1045-1072 (2016)

23. O. Urban, K. Klem, A. Ac, K. Havrankova, P. Holisova, M. Navratil, M. Zitova, K. Kozlova, R. Pokorny, M. Sprtova, I. Tomaskova, V. Spunda, J. Grace, Funct. Ecol. 26, 46-55 (2012)

24. F. Charbonnier, G. Maire, E. Dreyer, F. Casanoves, M. Christina, J. Dauzat, J.U.H. Eitel, P. Vaast, L.A. Vierling, O. Roupsard, Agric. For. Meteorol. 181, 152-169 (2013)

25. A.M.R. Petrescu, A. Lohila, J.-P. Tuovinen, D.D. Baldocchi, A.R. Desai, N. T. Roulet, T. Vesala, A.J. Dolman, W.C. Oechel, B. Marcolla, T. Friborg, J. Rinne, J.H. Matthes, L. Merbold, A. Meijide, G. Kiely, M. Sottocornola, T. Sachs, D. Zona, A. Varlagin, D.Y.F. Lai, E. Veenendaal, F.-J.W. Parmentier, U. Skiba, M. Lund, A. Hensen, J. van Huissteden, L.B. Flanagan, N.J. Shurpali, T. Grünwald, E.R. Humphreys, M. JackowiczKorczyński, M.A. Aurela, T. Laurila, C. Grüning, A.R. Chiara, C.A.R. Corradi, A.P. Schrier-Uijl, T.R. Christensen, M.P. Tamstorf, M. Mastepanov, P.J. Martikainen, S.B. Verma, C. Bernhofer, A. Cescatti, Proc. Natl. Acad. Sci. 112, 4594-4599 (2015)

26. I.S. Stachlewska, O. Zawadzka, R. Engelmann, Remote Sens. 9 (2017)

27. K. Markowicz, Metody pomiaru optycznych właściwości aerozolu atmosferycznego, in: K. JudaRezler, B. Toczko (ed.), Pyty drobne $w$ atmosferze: Kompendium wiedzy o zanieczyszczeniu powietrza pytem zawieszonym $w$ Polsce (Biblioteka Monitoringu Środowiska, Warszawa, 106-121, 2016)

28. O. Boucher, D. Randall, P. Artaxo, C. Bretherton, G. Feingold, P. Forster, V.-M. Kerminen, Y. Kondo, H. Liao, U. Lohmann, P. Rasch, S.K. Satheesh, S. Sherwood, B. Stevens and X.Y. Zhang, Clouds and Aerosols, in: T.F. Stocker, D. Qin, G.-K Plattner, M. Tignor, S.K. Allen, J. Boschung, A. Nauels, Y. Xia, V. Bex and P.M. Midgley (ed.), Climate Change 2013: The Physical Science Basis. Contribution of Working Group I to the Fifth Assessment Report of the Intergovernmental Panel on Climate Change (Cambridge University Press, Cambridge, United Kingdom and New York, NY, USA, 2013)

29. E.J. Freney, K. Adachi, P.R. Buseck, J. Geophys. Res. 115, D19210 (2010)

30. J.W. Fan, J. M. Comstock, M. Ovchinnikov, Environ. Res. Lett. 5 (2010)
31. R. Wood, J. Atmos. Sci. 64, 2657-2669 (2007)

32. R.A. Kahn, Surv. Geophys. 33, 701-721 (2012)

33. G. Pappalardo, A. Amodeo, A. Apituley, A. Comeron, V. Freudenthaler, H. Linné, A. Ansmann, J. Bösenberg, G. D’Amico, I. Mattis, L. Mona, U. Wandinger, V. Amiridis, L. AladosArboledas, D. Nicolae, M. Wiegner, Atmos. Meas. Tech. 7, 2389-2409 (2014)

34. J. Fuchs, J. Cermak, Remote Sens. 7, 4178-4190 (2015)

35. Y.J. Kaufman, D. Tanré, O. Boucher, Nature 419, 215-223 (2002)

36. G. Pappalardo, J. Bösenberg, A. Ansmann, D. Balis, C. Böckmann, A. Chaikovsky, A. Comeron, R. Eixmann, I.V. Grigorov, A. Hågård, V. Mitev, S. Nickovic, A. Papayannis, J. Pelon, M.R. Perrone, D. Resendes, V. Rizi, V. Simeonov, P. Sobolewski, N. Spinelli, T. Trickl, G. Vaughan, M. Wiegner, M. Zavrtanik, Aerosol Lidar measurements in the framework of EARLINET (2nd Symposium on Lidar Atmospheric Applications, Session 5, Lidar networks and Autonomous systems (5.1), 2005)

37. M. Aubinet, T. Vesala, D. Papale (ed.), Eddy covariance: A Practical Guide to Measurement and Data Analysis (Springer Atmospheric Sciences, p. 438, 2012)

38. B.H. Chojnicki, M. Urbaniak, D. Józefczyk, J. Augustin, J. Olejnik, Measurements of gas and heat fluxes at Rzecin wetland, in: T. Okruszko, E. Malby, J. Szatylowicz, D. Swiatek, W. Kotowski (ed.), Wetlands: Monitoring: Monitoring, Modeling and Menagement (Taylor \& Francis Group, London, England, 125-131, 2007)

39. F. Ulaby, D.G. Long, Microwave Radar and Radiometric Remote Sensing (Ann Arbor, Michigan, University of Michigan Press, 2014)

40. J. Delanoë, A. Protat, J.-P. Vinson, W. Brett, C. Caudoux, F. Bertrand, J. Parent du Chatelet, R. Hallali, L. Barthes, M. Haeffelin, J.-C. Dupont, J. Atmospheric Oceanic Technology 33, 1023-1038 (2016)

41. World Meteorological Organization. International Cloud Atlas. General classification of meteors Hydrometeors (Available online:

https://cloudatlas.wmo.int/, accessed on 11 April 2018)

42. American Meteorological Society. Glossary of Meteorology. Radar reflectivity factor (Available online:

http://glossary.ametsoc.org/wiki/Radar_reflectivity factor, accessed on 15 July 2018)

43. A. Kardaś, Badanie optycznych $i$ fizycznych własności aerozolu atmosferycznego $i$ czastek chmurowych na podstawie pomiarów teledetekcyjnych (Rozprawa doktorska, 2013)

44. D. Balis, V. Amiridis, S. Kazadzis, A. Papayannis, G. Tsaknakis, S. Tzortzakis, N. Kalivitis, M. Vrekoussis, M. Kanakidou, N. Mihalopoulos, 
G. Chourdakis, S. Nickovic, C. Pérez, J. Baldasano, M. Drakakis, Annales Geophysicae 24, 807-821 (2006)

45. U. Wandinger, Introduction to Lidar, in: C. Weitkamp (ed.), Lidar (Springer New York, 102, 1-18, 2005)

46. L. Belegante, J.A. Bravo-Aranda, V. Freudenthaler, D. Nicolae, A. Nemuc, D. Ene, L. AladosArboledas, A. Amodeo, G. Pappalardo, G. D'Amico, F. Amato, R. Engelmann, H. Baars, U. Wandinger, A. Papayannis, P. Kokkalis, S.N. Pereira, Atmos. Meas. Tech. 11, 1119-1141 (2018)

DOI: $10.5194 / \mathrm{amt}-11-1119-2018$

47. Raymetrics S.A., LR321-D300 Raman Depolarization LIDAR: User Manual (2017)

48. Raymetrics S.A., Lidar Analysis: User Manual (2018)

49. J.D. Vande Hey, Theory of Lidar, in: A Novel Lidar Ceilometer (Springer International Publishing Switzerland, 23-41, 2015)

50. C. Pérez, S. Nickovic, J.M. Baldasano, M. Sicard, F. Rocadenbosch, V.E. Cachorro, J. Geophys. Res. 111 (2006)

51. A. Smirnov, B.N. Holben, T.F. Eck, O. Dubovik, I. Slutsker, Remote Sens. Environ. 73, 337-349 (2000)

52. B.N. Holben, T.F. Eck, I. Slutsker, D. Tanre, J.P. Buis, A. Setzer, E. Vermote, J.A. Reagan, Y.J. Kaufman, T. Nakajima, F. Lavenu, I. Jankowiak, A. Smirnov, Remote Sens. Environ. 66, 1-16 (1998)

53. E.K. Webb, G. Pearman, R. Leuing, Q. J. R. Meteorol. Soc. 106, 85-100 (1980)

54. M. Reichstein, E. Falge, D. Baldocchi, D. Papale, M. Aubinet, P. Berbigier, C. Bernhofer, N. Buchmann, T. Gilmanov, A. Granier, T. Grünwald, K. Havránkov, H. Ilvesniemi, D. Janous, A. Knohl, T.Laurila, A. Lohila, D. Loustau, G. Matteucci, T. Meyers, Glob. Chang. Biol. 11, 1424-1439 (2005)

55. J. Wood, T. Muneer, J. Kubie, J. Sol. Energy Eng. 125, 1-6 (2003)

56. J. Lloyd, J.A. Taylor, Functional Ecology 8, 315323 (1994)

57. R.R. Draxler, G.D. Rolph, HYSPLIT (HYbrid SingleParticle Lagrangian Integrated Trajectory), Model access via NOAA ARL READY Website, NOAA Air Resources Laboratory (Silver Spring, MD, USA, 2010, Available online: https://www.ready.noaa.gov/HYSPLIT.php)

58. P. Lynch, J.S. Reid, D.L. Westphal, J. Zhang, T.F. Hogan, E.J. Hyer, C.A. Curtis, D.A. Hegg, Y. Shi, J.R. Campbell, J.I. Rubin, W.R. Sessions, F.J. Turk, A.L. Walker, Geosci. Model Dev. 9, 1489-1522 (2016),

Available online: https://www.nrlmry.navy.mil
59. Global Fire Maps, (Available online: https://lance.modaps.eosdis.nasa.gov/cgibin/imagery/firemaps.cgi, accessed on 15 July 2018)

60. M. Kleniewska, B.H. Chojnicki, M. Acosta, Meteorol. Hydrolo. Water Manage. 4, 35-40 (2016)

61. D.G.G. De Pury, G.D. Farquhar, Plant Cell Environ. 20, 537-557 (1997)

62. L. Mercado, J. Lloyd, F. Carswell, Y. Malhi, P. Meir, A.D. Nobre, Acta Amazon. 36, 69-82 (2006)

63. A. Knohl, D.D. Baldocchi, J. Geophys. Res. 113 (2008) 